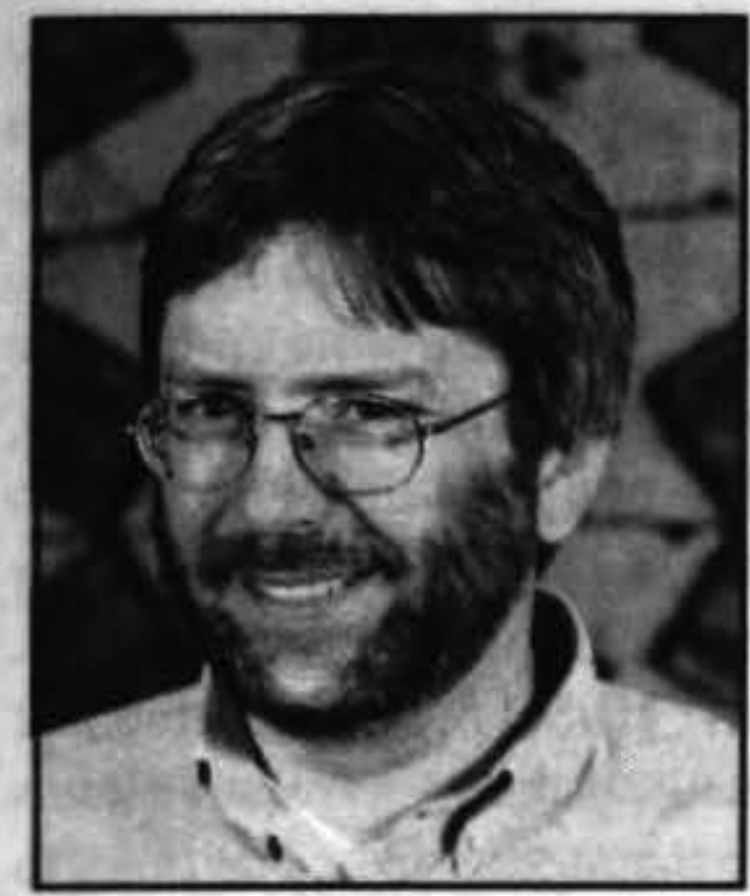

\title{
THE GROWTH AND GENDER COMPOSITION OF NEW ZEALAND'S INFORMATION WORK FORCE
}

\author{
Hans-Jürgen Engelbrecht
}

\author{
College of Business \\ Massey University
}

This paper documents the continuing growth and gender composition of New Zealand's information work force, at the aggregate level as well as by major occupation groups, over the period 1976-96. Information occupations have been selected from five-yearly Census occupation data at the four-digit level. After lagging behind the US in the past, the relative size of New Zealand's information work force now seems similar to that of the US. By 1996, about 55 percent of the female work force was employed in information occupations, compared to 40 percent of the male work force. There seems to have been relatively faster upskilling of the female information work force. The paper also briefly comments on related, but much narrower, 'knowledge worker' concepts, i.e. $R \& D$ personnel and the workers of the 'digital' economy, and on some of the problems encountered if one wants to relate the workforce measures to endogenous growth theory. Finally, a long wish list of further research is provided.

Keywords: Information workers, the knowledge economy, gender.

The concepts of the 'knowledge economy' and 'knowledge society' have recently received increased attention from New Zealand (NZ) researchers and policy makers (see, e.g., Frederick and McIlroy, 1999, and MoRST, 2000a). After expecting a 'Bright Future', the Ministry of Research, Science and Technology is now to 'Ignite the Future' (MoRST, 1999a, 2000b). Some common features of a knowledge society are that knowledge and information have become the major sources of creating value, rapid changes in technology, especially in information technologies (IT), greater R\&D investments, rising skill requirements, etc. (ibid.). However, it tends to be forgotten that there is a long history of the analysis of changes towards an information or knowledge economy which predates much of the recent hype about the knowledge economy and related (but mostly narrower) concepts, like the 'new', the 'weightless', the 'digital', the 'Internet'-economy, etc.

Some of the seminal earlier studies for the US are Machlup (1962), Bell (1973) and Porat and Rubin (1977), who analysed the fundamental shift in the work force away from manual work towards information/knowledge work. Many OECD studies were also devoted to these changes. The US data on information workers have recently been updated by Martin (1998, 1999). Earlier NZ studies include Conway (1981) and Dordick (1987).

This study focuses on the measurement of NZ's information work force by gender. In order to highlight the longterm changes, and building on Conway's (1981) earlier estimates, the author has updated the measurement of NZ's information work force for the period 1976-96 and found that it had increased greatly in size (Engelbrecht, 2000a,b). The economic reforms since 1984 seem to have led to a dramatic restructuring of the country's information work force. From lagging considerably behind the US in terms of the relative size of its information work force, NZ now seems to have caught up with the US in that respect. This somewhat surprising finding also raises questions concerning the meaning of the term 'knowledge economy', especially given the patchy productivity growth performance of the NZ economy, the growth of the 'transaction sector', the seemingly weak National Innovation System etc. It would be simplistic to assume that there is only one kind of knowledge economy, i.e. that of the high productivity, high wage, high-tech variety. However, such questions are beyond the objective of this paper. It is hoped that this study will stimulate further research not only into NZ's information work force, but also into the question which knowledge economy model and policies might be appropriate for NZ.

After discussing the changes in NZ information work force, comments are provided on the relationship between new growth theory and different measures of information and knowledge workers. Next, a large number of directions for further research are suggested. Finally, an appendix provides details of the delineation of information workers used in this study. 


\section{New Zealand's Information Work Force 1976-96}

I broadly follow the OECD (1981) inventory of information occupations, which was also used by Conway (1981). Information workers are defined as those working in occupations whose primary purpose is an output of produced, processed or distributed information, or its infrastructure support (i.e. occupations primarily engaged in installing, operating and repairing information machines and technologies)(see OECD, 1981, pp. 22-3). However, because occupation classifications change over time, new information occupations are being created, and the data might not be detailed enough to distinguish some information from non-information occupations, subjective choices and compromises are always involved in the delineation of the information work force. The approach taken here is to modify, where appropriate, the list of information occupations identified by Conway (1981) in order to increase comparability of the estimates over the 1976-96 period. The selection of information occupations and other data issues are discussed in the appendix.

\section{The Growth of the Information Work Force}

Before reporting the gender specific estimates, it is useful to provide aggregate data on the growth of information occupations in NZ over time (see Table 1). It should be noted that my estimates are more conservative, i.e. lower, than those of others. It should also be noted that all percentages reported for 1991 are likely to be overstated and misleading. due to the high level of unemployment that year, which seems to have affected information workers less than other workers.

The data in Table 1 indicate the persistent growth of NZ's

Table 1. The Relative Size of New Zealand's Information Work Force Over Time (Fulltime Workers Only)

\begin{tabular}{cc}
\hline Year & \% Information Workers \\
\hline 1956 & 25.7 \\
1961 & 28.9 \\
1966 & 30.3 \\
1971 & 33.7 \\
1976 & $35.9 / 34.6$ \\
1981 & 35.0 \\
1986 & 38.3 \\
1991 & 44.6 \\
1996 & 45.7 \\
\hline
\end{tabular}

Source: The percentages for 1956 to 1976 shown in italics are taken from Conway (1981). The other percentages are own estimates calculated from the various New Zealand Census of Population and Dwellings reports (Department of Statistics, 1980, Table 9, 1983, Table 15, 1988, Table 8; Statistics New Zealand. 1997, 1999). information work force. Its relative size now seems very similar to that of the US: Martin (1998) reports that in 1980 , the US information work force accounted for $44.1 \%$ of all employed, whereas in 1995 it accounted for $45.8 \%$. In contrast to the US, the NZ information work force grew faster during the 1986-96 decade compared to 1976-86. In the past, some analysts have argued that information work force growth in NZ had come to a halt, despite the still small relative size of the NZ information work force. For example, Parrot and Forer (1986, p. 29) reported that the information work force actually shrunk in relative terms during the late 1970 s, due to the recession at that time. In contrast, the restructuring and recession of the late $1980 \mathrm{~s} /$ early 1990s seem to have had the opposite effect.

\section{The Overall Trend by Gender}

Many analysts of information employment, e.g. Porat and Rubin (1977), Conway (1981), Kling (1990), Castells (1996) and Martin $(1998,1999)$, do not report data by gender. The data in Table 2 indicate that, in absolute terms, there are fewer full-time female information workers compared to full-time male information workers in NZ. However, females are much more concentrated in information occupations compared to males. Since the mid-1980s, the majority of females in the work force have been employed in information occupations, whereas even in 1996, the percentage for males was only around $40 \%$.

Because a change in the definition of part-time employment occurred between 1981 and 1986, part-time employment data are only reported for the years 1986, 1991 and 1996. Previously, part-time employment was defined as comprising all persons 15 years of age and over who were normally employed for less than 20 hours a week. This was changed to less than 30 hours a week from the 1986 Census onwards (Department of Statistics, 1988).

As can be seen from Table 3, part-time employment is dominated by females, both in relative as well as in absolute terms. However, for all years and for both gender, the percentage of information employment is smaller than that in the full-time work force (compare Tables 2 and 3), and has changed little over the decade 1986-96. The higher unemployment in 1991 seems to have affected non-information part-time employment to a much greater extent than information part-time employment.

It is also noteworthy that the general trend towards parttime employment during 1986-96 was less strong for information workers compared to non-information workers (see Engelbrecht, 2000b).

\section{Changes by Major Categories of Information Workers}

The gender breakdown of the information work force by major occupation groups is reported next (Tables 4 and 5). All information workers in major groups $A$ and $B$ are regarded as high-skilled. Davis et al. (1997) recognize these groups as having the highest socio-economic status in NZ society. The data show that high-skilled workers make up a relatively larger proportion of the male, compared to the 
female, information work force, though the high-skilled proportion has risen for both males and females over time (from $47.4 \%$ of the full-time male information work force in 1976 to $61.5 \%$ in 1996 , and from $24.4 \%$ of the full-time female information work force in 1976 to $41 \%$ in 1996). This indicates upskilling of the NZ information work force. Clerical occupations are still the largest occupation group for females, but its relative size seems to be shrinking rapidly.

To sum up, while full-time information occupations make up a larger proportion of total full-time employment for females compared to males, males are still more reforms and the severe recession of the late 1980s/early 1990 s, which decimated the manufacturing sector. Nearly $26 \%$ of the manufacturing work force was lost during the 1980s (Willis, 1995). Moreover, deregulation of the financial sector and other policy changes let to a rise in information-intensive administrative and managerial positions. However, some of the changes may reflect reclassification of occupations due to the adoption of the new, skill-based, 1988 International Standard Classification of Occupations (ISCO) (see the appendix).

Changes among major occupation groups are less pronounced for the part-time information work force,

\section{Table 2. The Full-time New Zealand Information Work Force by Gender}

\begin{tabular}{|c|c|c|c|c|}
\hline Year & Gender & Total & Information workers & $\%$ Info. Workers \\
\hline \multirow[t]{2}{*}{1976} & Male & 850,706 & 248,716 & 29.2 \\
\hline & Female & 395,290 & 182,201 & 46.1 \\
\hline \multirow[t]{2}{*}{1981} & Male & 842,127 & 246,957 & 29.3 \\
\hline & Female & 429,960 & 197,937 & 46.0 \\
\hline \multirow[t]{2}{*}{1986} & Male & 841,338 & 271,353 & 32.3 \\
\hline & Female & 436,866 & 218,745 & 50.1 \\
\hline \multirow[t]{2}{*}{1991} & Male & 734,283 & 282,900 & 38.5 \\
\hline & Female & 416,919 & 230,895 & 55.4 \\
\hline \multirow[t]{2}{*}{1996} & Male & 778,317 & 310,596 & 39.9 \\
\hline & Female & 474,450 & 262,350 & 55.3 \\
\hline
\end{tabular}

Source: Own calculations from various Census reports (Department of Statistics, 1980, Tables 9, 1983, Table 15, 1988, Table 8, Statistics New Zealand, 1997, 1999).

\section{Table 3. The Part-time New Zealand Information Work Force by Gender}

\begin{tabular}{ccccc}
\hline Year & & Total & Information workers & \% Info. workers \\
\hline 1986 & Male & 48,996 & 10,692 & 21.8 \\
& Female & 172,218 & 62,117 & 36.1 \\
& & & & \\
1991 & Male & 60,789 & 14,166 & 23.3 \\
& Female & 188,415 & 81,126 & 43.1 \\
& & & 25,104 & 22.5 \\
\multirow{2}{*}{1996} & Male & 111,696 & 96,780 & 36.3 \\
\hline
\end{tabular}

Source: Various Census reports (Department of Statistics, 1988, Table 8, Statistics New Zealand, 1997, 1999).

concentrated in high-skilled information jobs. However, this difference has been shrinking over time, indicating relatively faster upskilling of female information workers. Overall, the proportion of high skilled information workers has increased from $13 \%$ of the total NZ full-time work force in 1976 to $23.7 \%$ in 1996.

Most of the changes among major occupation group shares between 1986 and 1991 will have been due to the economic though the evidence regarding upskilling differs markedly from that for full-time workers. Similar to full-time employment, the high-skilled groups $\mathrm{A}$ and $\mathrm{B}$ make up the majority of part-time male information employment, in contrast to female part-time employment (see Tables 6 and 7). However, there seems to have been relative de-skilling of male part-time employment. The proportion of groups $A$ and $B$ has fallen from $63 \%$ in 1986 to $54.5 \%$ in 1996 . In contrast, the proportion of high-skilled part-time 
Table 4. Composition of the Full-time New Zealand Male Information Work Force by Major Category

\begin{tabular}{|c|c|c|c|c|c|}
\hline & $\begin{array}{c}1976 \\
\text { No. }(\%) \\
\end{array}$ & $\begin{array}{c}1981 \\
\text { No. }(\%) \\
\end{array}$ & $\begin{array}{c}1986 \\
\text { No. }(\%) \\
\end{array}$ & $\begin{array}{c}1991 \\
\text { No. }(\%) \\
\end{array}$ & $\begin{array}{c}1996 \\
\text { No. }(\%) \\
\end{array}$ \\
\hline A. Professional etc. & $\begin{array}{c}80,003 \\
(32.2)(9.4)\end{array}$ & $\begin{array}{c}80.229 \\
(32.5)(9.5)\end{array}$ & $\begin{array}{c}87,510 \\
(32.2)(10.4)\end{array}$ & $\begin{array}{c}94,500 \\
(33.4)(12.9)\end{array}$ & $\begin{array}{c}105,513 \\
(34.0)(13.6)\end{array}$ \\
\hline $\begin{array}{l}\text { B. Administrative and } \\
\text { managerial }\end{array}$ & $\begin{array}{c}37,941 \\
(15.2)(4.4)\end{array}$ & $\begin{array}{c}42,003 \\
(17.0)(5.0)\end{array}$ & $\begin{array}{c}59,889 \\
(22.1)(7.1)\end{array}$ & $\begin{array}{c}79,092 \\
(28.0)(\mathbf{1 0 . 8})\end{array}$ & $\begin{array}{c}84,978 \\
(27.3)(\mathbf{1 0 . 9})\end{array}$ \\
\hline C. Clerical & $\begin{array}{c}67.092 \\
(27.0)(7.9)\end{array}$ & $\begin{array}{c}63,324 \\
(25.7)(7.5)\end{array}$ & $\begin{array}{c}62,076 \\
(22.9)(7.4)\end{array}$ & $\begin{array}{c}34,500 \\
(12.2)(4.7)\end{array}$ & $\begin{array}{c}39,951 \\
(12.9) \quad(5.1)\end{array}$ \\
\hline D. Sales & $\begin{array}{c}46,094 \\
(18.5)(5.4)\end{array}$ & $\begin{array}{c}42,828 \\
(17.3)(5.1)\end{array}$ & $\begin{array}{c}43,605 \\
(16.1)(5.2)\end{array}$ & $\begin{array}{c}57,459 \\
(20.3) \quad(7.8)\end{array}$ & $\begin{array}{c}63,249 \\
(20.4)(8.1)\end{array}$ \\
\hline E. Production & $\begin{array}{c}17,586 \\
(7.1) \quad(2.1)\end{array}$ & $\begin{array}{c}18,573 \\
(7.5) \quad(2.2)\end{array}$ & $\begin{array}{c}18,273 \\
(6.7) \quad(2.2)\end{array}$ & $\begin{array}{c}17,349 \\
(6.1) \quad(2.3)\end{array}$ & $\begin{array}{c}16,905 \\
(5.4) \quad(2.2)\end{array}$ \\
\hline $\begin{array}{l}\text { Total information } \\
\text { work force }\end{array}$ & $\begin{array}{c}248,716 \\
(100)(29.2)\end{array}$ & $\begin{array}{c}246,957 \\
(100)(29.3)\end{array}$ & $\begin{array}{c}271,353 \\
(100)(32.3)\end{array}$ & $\begin{array}{c}282,900 \\
(100)(38.5)\end{array}$ & $\begin{array}{c}310,596 \\
(100)(39.9)\end{array}$ \\
\hline
\end{tabular}

Note: The numbers in the first brackets indicate the percentage of the information work force, and in the second, the percentage of the total Work force (in bold). Source: See table 2.

Table 5. Composition of the Full-time New Zealand Female Information Work Force by Major Category

\begin{tabular}{|c|c|c|c|c|c|}
\hline & $\begin{array}{c}1976 \\
\text { No. }(\%)\end{array}$ & $\begin{array}{c}1981 \\
\text { No. }(\%)\end{array}$ & $\begin{array}{c}1986 \\
\text { No. }(\%) \\
\end{array}$ & $\begin{array}{c}1991 \\
\text { No. }(\%)\end{array}$ & $\begin{array}{c}1996 \\
\text { No. }(\%) \\
\end{array}$ \\
\hline A. Professional etc. & $\begin{array}{c}41.552 \\
(22.8)(\mathbf{1 0 . 5})\end{array}$ & $\begin{array}{c}44,430 \\
(22.4)(\mathbf{1 0 . 3})\end{array}$ & $\begin{array}{c}48,153 \\
(22.0)(\mathbf{1 1 . 0})\end{array}$ & $\begin{array}{c}57,606 \\
(25.0)(\mathbf{1 3 . 8})\end{array}$ & $\begin{array}{c}72,573 \\
(27.7)(15.3)\end{array}$ \\
\hline $\begin{array}{l}\text { B. Administrative and } \\
\text { managerial }\end{array}$ & $\begin{array}{c}2,861 \\
(1.6) \quad(0.7)\end{array}$ & $\begin{array}{c}3.687 \\
(1.9) \quad(0.9)\end{array}$ & $\begin{array}{c}10,371 \\
(4.8) \quad(2.4)\end{array}$ & $\begin{array}{c}27,120 \\
(11.7)(6.5)\end{array}$ & $\begin{array}{c}34,974 \\
(13.3) \quad(7.4)\end{array}$ \\
\hline C. Clerical & $\begin{array}{c}127.592 \\
(70.0)(32.3)\end{array}$ & $\begin{array}{c}135,837 \\
(68.6)(\mathbf{3 1 . 6})\end{array}$ & $\begin{array}{c}141,378 \\
(64.6)(32.4)\end{array}$ & $\begin{array}{c}110,379 \\
(47.8)(26.5)\end{array}$ & $\begin{array}{c}110,112 \\
(42.0)(23.2)\end{array}$ \\
\hline D. Sales & $\begin{array}{c}5,797 \\
(3.2) \quad(\mathbf{1 . 5})\end{array}$ & $\begin{array}{c}9,066 \\
(4.6) \quad(2.1)\end{array}$ & $\begin{array}{c}12,768 \\
(5.8) \quad(2.9)\end{array}$ & $\begin{array}{c}31,320 \\
(13.6) \quad(7.5)\end{array}$ & $\begin{array}{c}39,498 \\
(15.0) \quad(8.3)\end{array}$ \\
\hline E. Production & $\begin{array}{c}4,399 \\
(2.4) \quad(\mathbf{1 . 1})\end{array}$ & $\begin{array}{c}4,917 \\
(2.5) \quad(1.1)\end{array}$ & $\begin{array}{c}6,075 \\
(2.8) \quad(1.4)\end{array}$ & $\begin{array}{c}4,470 \\
(1.9) \quad(1.1)\end{array}$ & $\begin{array}{c}5,193 \\
(2.0) \quad(1.1)\end{array}$ \\
\hline $\begin{array}{l}\text { Total information } \\
\text { work force }\end{array}$ & $\begin{array}{c}182,201 \\
(100)(46.1)\end{array}$ & $\begin{array}{c}197,937 \\
(100)(46.0)\end{array}$ & $\begin{array}{c}218,745 \\
(100)(50.1)\end{array}$ & $\begin{array}{c}230,895 \\
(100)(55.4)\end{array}$ & $\begin{array}{c}262,350 \\
(100)(55.3) \\
\end{array}$ \\
\hline
\end{tabular}

Note: The numbers in the first brackets indicate the percentage of the information work force, and in the second, the percentage of the total work force (in bold). Source: See table 2.

occupations for females has increased from $31.2 \%$ in 1986 to $37.8 \%$ in 1996 , although the majority of female parttime information jobs are still in the clerical group and the extent of upskilling seems much less than that of full-time female information workers.

\section{The Information Work Force and New Growth Theory}

NZ's information work force has grown steadily over time, approaching half of the total work force, and its composition has changed greatly. This phenomenon should not be confused with developments in other, much narrower and partly overlapping, sub-categories of the information work force.

One way of looking at the 'new economy' part of the knowledge economy is to focus on changes in IT occupations, i.e. changes in the work force of the 'digital economy' (US Department of Commerce, 2000). So far such work- ers make up only a small fraction of the work force, though their number is expected to grow strongly. For NZ, it has been reported that in both 1991 and 1996, about $4 \%$ of the working population were employed in IT occupations and/or working for an IT industry company (Ministry of Economic Development, 2000, p. 11). In terms of occupations, only eight are identified at the 5-digit level, ranging from unskilled to highly skilled and managerial. Female IT workers tend to be less skilled than males (ibid., pp. $15-17)$. In 1996 , there were 64,770 IT workers in NZ (ibid., p. 11).

Another way of looking at the knowledge economy is to focus on research and development (R\&D) personnel. Internationally comparable data on R\&D personnel in NZ are contained in the official R\&D publications. These workers make up a small group. For example, in 1997/98 there were 12,899 full-time equivalent R\&D staff, comprising researchers (including engineers), technicians and support staff, up from 10,547 in 1995/6 (MoRST, 1999b, 
Table 6. Composition of the Part-time New Zealand Male Information Work Force by Major Category

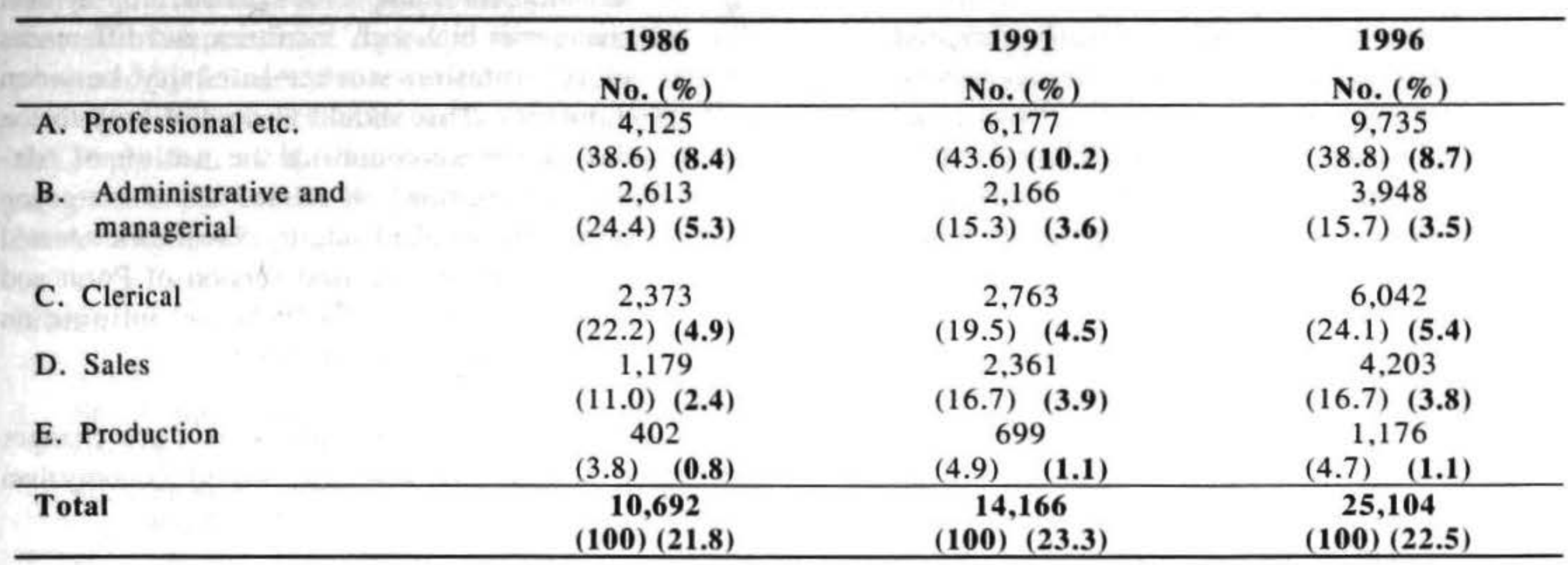

Note: The numbers in the first brackets indicate the percentage of the part-time information work force, and in the second, the percentage in the total part-time work force (in bold). Source: See table 3.

Table 7. Composition of the Part-time New Zealand Female Information Work Force by Major Category

\begin{tabular}{|c|c|c|c|}
\hline & $\begin{array}{c}1986 \\
\text { No. }(\%)\end{array}$ & $\begin{array}{c}1991 \\
\text { No. }(\%)\end{array}$ & $\begin{array}{c}1996 \\
\text { No. }(\%)\end{array}$ \\
\hline A. Professional etc. & $\begin{array}{c}16,491 \\
(26.5) \quad(9.6)\end{array}$ & $\begin{array}{c}27,945 \\
(34.5)(\mathbf{1 4 . 8})\end{array}$ & $\begin{array}{c}29.610 \\
(30.6)(11.1)\end{array}$ \\
\hline $\begin{array}{l}\text { B. Administrative and } \\
\text { managerial }\end{array}$ & $\begin{array}{c}2,886 \\
(4.7) \quad(1.7)\end{array}$ & $\begin{array}{c}4,716 \\
(5.8) \quad(2.5)\end{array}$ & $\begin{array}{c}7,023 \\
(7.2)^{(2.6)}\end{array}$ \\
\hline C. Clerical & $\begin{array}{c}39,432 \\
(63.5)(22.9)\end{array}$ & $\begin{array}{c}42,375 \\
(52.2)(\mathbf{2 2 . 5})\end{array}$ & $\begin{array}{c}50,715 \\
(52.4)(\mathbf{1 9 . 0})\end{array}$ \\
\hline D. Sales & $\begin{array}{c}2,387 \\
(3.8) \quad(1.4)\end{array}$ & $\begin{array}{c}5,202 \\
(6.4) \quad(2.8)\end{array}$ & $\begin{array}{c}8,109 \\
(8.4) \quad(3.1)\end{array}$ \\
\hline E. Production & $(1.5)^{921}(0.5)$ & $(1.1)^{888}(0.5)$ & $\begin{array}{c}1,323 \\
(1.4) \quad(0.5)\end{array}$ \\
\hline Total & $\begin{array}{c}62,117 \\
(100)(36.1)\end{array}$ & $\begin{array}{c}81,126 \\
(100)(43.1)\end{array}$ & $\begin{array}{c}96,780 \\
(100)(36.3)\end{array}$ \\
\hline
\end{tabular}

Note: The numbers in the first brackets indicate the percentage of the part-time information work force, and in the second, the percentage in the total part-time work force (in bold). Source: See table 3.

p. 8/9). On the other hand, a detailed study of NZ's human resources in science \& technology in 1996 reports larger figures: the total number of such human resources accounted for 14.7 percent of the population ( 535,374 people); employed scientists and engineers constituted $2.98 \%$ of the total labour force $(48,546$ people) (MoRST, 1998). It is not explained how these statistics relate to those given in the official NZ R\&D statistics.

Changes in R\&D personnel and in the digital work force capture much narrower occupation changes than does the broad measure of the information work force used in this study. Without recourse to economic theory it is not clear which work force variable should be preferred for analysing the knowledge economy. The choice depends on which questions are to be addressed using what model(s).

Advocates of the knowledge economy often invoke 'new' or 'endogenous' growth theory in support of their argu- ments. This branch of growth theory endogenizes the role of knowledge. However, the policy implications of new growth theory are far from clear. This is mainly due to two major problems. Firstly, there are many different types of endogenous growth models. To name but two broad groups, there are 'ideas' models in contrast to human capital models. The former focus on knowledge or R\&D embodied in the use of new capital goods (i.e. non-labour inputs), whereas the latter focus on skills, which either solely accrue to the person, investing in those skills or which can also raise the productivity of other workers. Also, depending on which human capital growth model is chosen, human capital can be approximated by a variable like $R \& D$ personnel, or it can cover a much wider group of occupations. Until we know which growth model, or which combination of models, applies in the case of NZ, we don't know which human capital variable(s) to focus on.

The second, and related, major problem is that the key concepts associated with the term knowledge economy are 
so difficult to measure. Aghion and Howitt (1998, p. 435) have noted that:

\begin{abstract}
we do not have any generally accepted empirical measures of such key theoretical concepts as the stock of technological knowledge, human capital, the resource cost of knowledge acquisition, the rate of innovation, the rate of obsolescence of old knowledge, and so forth... formal theory is ahead of conceptual clarity.
\end{abstract}

In short, we don't yet know what the relevant key variables are, or how to measure them appropriately. Until these issues are resolved, it is difficult to know what economic policies the government should pursue to foster development of the knowledge economy in NZ.

\section{Future Research}

This study has documented the shift towards a high-skilled information work force in NZ during a period of tumultuous economic and social change. In some respects the work force data are encouraging, but their interpretation remains controversial, and there are many gaps in our knowledge that await further research. For example, the current study could be extended and refined in many ways:

- One could try to analyze the information work force by age group and ethnicity.

- One could investigate its geography. What is its geographical concentration? Is it changing over time?

- One could focus on unemployment amongst different types of information workers, as well as between information and non-information workers.

- The migration of information workers needs to be investigated. For example, in what sense might there be a 'brain drain'?

- The analysis of gender differences in the information work force could be refined by trying to adjust for the inevitable inaccuracies involved in using occupation data. Kirkwood (1999), referring to research conducted by the NZ Planning Council, has pointed out that the occupational classification gives little indication of status within each occupation. For example, females may be employed at a lower level within occupations than their male counterparts. In this context, the question arises by how much the finding of faster upskilling of the female information work force might be biased.

- Kirkwood (ibid.) also noted that full-time employed females seem to work fewer hours then males in all occupation groups (at the 1-digit level). A refined measurement of the information work force by gender could be based on hours worked.

- A logical next step in the analysis would be to look at changes in the information work force by industry. This would highlight changes in industry structure, for example the extent of employment changes in 'high-tech' industries, and differences in information worker intensity between industries. This should also contribute to the discussion surrounding the notion of 'deindustrialisation'. A related approach going beyond the standard industry classification would be to estimate a revised version of Porat and Rubin's 'secondary' or 'in-house' information sector (see Engelbrecht, 1997b).

There are other ways of measuring work force changes towards an information or knowledge-based economy than selecting certain occupations as informational:

- One could try and analyze broad skill changes in the economy over time drawing on the detailed skill profile of each occupation. Using the US Dictionary of Occupational Titles (DOT) (US Department of Labor, 1991), researchers have been able to analyze the changing importance of different types of skills, for example cognitive, interactive and motor skills, by industry and for the whole economy (see, e.g., Schement and Lievrouw, 1984, Pappas, 1998). Since late 1998, DOT has been superseded by $\mathrm{O} * \mathrm{NET}$ (Occupational Information Network) which is more appropriate for today's information-based occupations. The use of the latter needs to be explored in the NZ context.

- A related approach is to use longitudinal career history data to define knowledge workers and to trace their flow over time and across sectors. Using British survey data, Tomlinson (1999) used this approach and was able to measure the more intangible aspects of knowledge workers, such as learning and tacit knowledge, and trace their flow through the economy as workers changed employment.

A major area of research usually associated with the growth of the information work force that has not been addressed in this study is skill-biased technological change and the impact of IT. The main reason is lack of NZ data. However, the topic clearly requires further research. We need capital stock estimates, including IT capital stock estimates, at a level detailed enough to use in econometric analysis. Without it, we cannot determine to what extent the work force changes in NZ have been due to technological change, the economic reforms, and other factors. Suffice to say that the international evidence concerning the role of IT is far from clear. For example, it is controversial what the relationships are between computer use, upskilling and higher wages. It is currently not clear whether the productivity gains associated with the 'new economy' in the US and elsewhere are confined to 'high-tech' IT producing industries, or whether they are spilling over to IT using industries. 
Gender differences with respect to technological change also need to be explored. To provide just one example, there is evidence from Australia that computer skills possessed by females are rewarded at a higher rate that equivalent skills possessed by males (Hawke, 1998). Does this imply that, as Hawke suggests, increasing female computer literacy might be a way of further reducing the gender wage gap?

\section{Notes}

1 Space limitations preclude discussion of the different concepts. See Claus and Smith (2000) for an assessment of the 'new economy' argument in the NZ case. For references to the weightless economy, see Danny Quah's webpage http://econ.lse.ac.uk/ dquah/ . On the digital economy, see US Department of Commerce (2000). For an attempt to measure the Internet economy, see http:// www.internetindicators.com.

2 But see Engelbrecht (2000a,b), who discusses some of the features and paradoxes associated with NZ's 'economic experiment' and raises questions about policies for a knowledge economy. For a discussion of the diversity of occupational structures of 'informational' societies see, e.g., Castells (1996, chapter 4). Hodgson (1999) has discussed the possibility of different knowledge economy utopia.

3 See the discussion in Engelbrecht (2000b).

4 It should be noted that female earnings grew more rapidly than male earnings between 1984 and 1997 , leading to a reduction in the gender earnings gap (see Dixon, 1998, p. 89). This is consistent with the finding of faster upskilling of the female information work force.

4 It should be noted that the broad measure of the information work force adopted in this study can be used in further economic analysis, especially when available at the industry level (see the survey in Engelbrecht, 1997a). One example is production function analysis.

6 See Klenow (1998) for references.

7 It has been estimated that the proportion of embodied R\&D to total R\&D is very high in the NZ case (Walker and Liu, 1998).

8 Another common way of measuring human capital, especially in cross-country growth studies, is to use average years of schooling or a similar education measure as proxy. Suffice to say that the modeling of human capital in growth regressions is controversial (see, e.g., Temple, 2000).
9 OECD (1998) provides some internationally comparable analysis of changes in occupations (four skill categories) by industry in NZ. For example, it shows that the percentage of manufacturing employment in 'high-tech' industries has fallen from $3.5 \%$ in 1976 to $2.6 \%$ in 1996 ; similarly, manufacturing employment in 'high and medium-high tech' industries has fallen over the same period from $22.5 \%$ to $19.6 \%$.

10 See http://www.doleta.gov/programs/onet/

11 See Engelbrecht (2000b) for some key references.

12 I thank Sarah Black for competent research assistance.

\section{References}

Aghion, P. and Howitt, P. (1998) Endogenous Growth Theory, Cambridge, Mass. MIT Press.

Bell, D. (1973) The Coming of Post-Industrial Society. New York: Basic Books.

Castells, M. (1996) The Rise of the Network Society, Oxford: Blackwell Publishers.

Claus, I. and Smith, C. (2000) What's the 'New Economy"? And has it crossed the Pacific to New Zealand? Reserve Bank of New Zealand Bulletin, 63(3), 16-29. http://www.rbnz.govt.nz/research/ bulletin/index.html

Conway, M. (1981) Information Occupations: The New Dominant in the New Zealand Work Force, Communications Policy Research Group, Commission for the Future (eds.), Network New Zealand Working Papers, Paper No. 2.

Davis, P. McLeod, K. Ransom, M. and Ongley P. (1997) The New Zealand Socioeconomic Index of Occupational Status (NZSEI), Research Report \#2, Wellington: Statistics New Zealand.

Department of Statistics (1980) New Zealand Census of Population and Dwellings 1976, Volume 4, Labour Force, Wellington.

Department of Statistics (1983) New Zealand Census of Population and Dwellings 1981, Volume 4, Labour Force, Wellington.

Department of Statistics (1988) 1986 New Zealand Census of Population and Dwellings, Labour Force Part 1, Series C, Report 4, Wellington.

Dixon, S. (1998) Growth in the Dispersion of Earnings: 1984-97, Labour Market Bulletin, 1\&2: 71-107. 
Dordick, H.S. (1987) Information Technology \& Economic Growth in NZ, Wellington: Victoria University Press for the Institute of Policy Studies.

Engelbrecht, H. J. (1997a) The International Economy, Knowledge Flows and Information Activities. Lamberton. D (ed.), The New Research Frontiers of Communication Policy. Amsterdam: Elsevier Science, 19-42.

Engelbrecht, H. J. (1997b) A Comparison and Critical Assessment of Porat and Rubin's information economy and Wallis and North's transaction sector, Information Economics and Policy, 9: 271-290.

Engelbrecht, H. J. (2000a) Changes in the Information Work Force of a Strongly Reforming Economy: The case of New Zealand 1976-1996, Discussion Paper No. 00.07, Department of Applied and International Economics, Massey University, Palmerston North. http://econ.massey.ac.nz/ discuss.html

Engelbrecht, H.-J. (2000b) Towards a Knowledge Economy? Changes in New Zealand's Information Work Force 1976-1996, Prometheus, 18(3): 265282.

Frederick, H. and McIlroy, D. (1999) The Knowledge Economy, Wellington: The New Zealand Internet Institute. http://www.knowledge.gen.nz

Hawke, A. (1998) Gender Differences in Wage Returns to Computer Skills in Australia. Prometheus, 16 (1): 5-12.

Hodgson, G. (1999) Economics \& Utopia: Why the Learning Economy is not the End of History. London: Routledge.

Kirkwood, H. (1999) Exploring the Gap: An Exploration of the Difference in Income Received from Wages and Salaries by Women and Men in Full-time Employment. Morrison, P. (ed.), Labour, Employment and Work in New Zealand 1998, Proceedings of the Eighth Conference, Institute of Geography, Victoria University of Wellington, 85-95.

Klenow, P. (1998) Ideas versus Rival Human Capital: Industry Evidence on Growth Models, Journal of Monetary Economics, 42: 3-23.

Kling, R. (1990) More Information, Better Jobs?: Occupational stratification and labor-market segmentation in the United States' information labor force. Information Society, 2 (2): 77-107.

Machlup, F. (1962) The Production and Distribution of
Knowledge in the United States, Princeton, N.J: Princeton University Press.

Martin, S. B. (1998) Information Technology, Employment, and the Information Sector: Trends in Information Employment 1970-1995. Journal of the American Society for Information Science, 49 (12): 1053-1069.

Martin, S.B. (1999) Employment in the Information Age. INFO, 1(3): 271-283.

Ministry of Economic Development (2000) Statistics on Information Technology in New Zealand 2000 (Information Technology Policy Group), Wellington.

http://www.med.govt.nz/pbt/infotech/currentstats

MoRST (1998) Human Resources in Science and Technology in New Zealand, Wellington. http:/ /www.morst.govt.nz/pubs/hr/index.htm

MoRST (1999a) Bright Future: Making Ideas Work for New Zealand, Wellington. http:// www.morst.govt.nz

MoRST (1999b) New Zealand Research and Development Statistics 1997/98, Publication No. 17, Wellington. http://www.morst.govt.nz

MoRST (2000a) Creating a Knowledge Society, Wellington.

http://www.morst.govt.nz/creating/

MoRST (2000b) Igniting the Future: Strategic Direction 2000-2003, Wellington. http:// www.morst.govt.nz/pubs/strat00/ strat_direction.pdf

OECD (1981) Information Activities, Electronics and Telecommunications Technologies: Impact on Employment, Growth and Trade, Volume 1, ICCP Report No. 6, Paris.

OECD (1998) OECD Data on Skills: Employment by Industry and Occupation, STI Working paper 1998/4, Economic Analysis and Statistics Division.

Pappas, N. (1998) Changes in the Demand for Skilled labour in Australia. Sheehan. P and Tegart. G (eds.), Working for the Future: Technology and Employment in the Global Knowledge Economy, Melbourne: Victoria University Press, 253-292.

Parrot, N. and Forer, P. (1986) The information sector in New Zealand 1971-1981, New Zealand Geographer, 42(1): 25-30.

Porat, M.U. and Rubin, M.R. (1977) The Information 
Economy (in nine volumes), Washington D.C: Government Printing Office.

Schement, J.R. and Lievrouw, L. (1984) A behavioural measure of information work, Telecommunications Policy, December: 321-338.

Statistics New Zealand (1995) New Zealand Standard Classification of Occupations 1995, Wellington.

Statistics New Zealand (1997) Census 96 [computer file]: with Supermap 3 and for GIS and mapping, Wellington.

Statistics New Zealand (1999) Census 1991 4-digit Occupation Data, Supplied on Request.

Temple, J. (2000) Growth Effects of Education and Social Capital in the OECD countries, Economics Department Working Papers No. 263, OECD: Paris.

http://www.oecd.org/eco/wp/onlinewp.htm\#2000

Tomlinson, M. (1999) The learning economy and embodied knowledge flows in Great Britain, Journal of Evolutionary Economics, 9 (4): 431451.

US Department of Commerce (2000) Digital Economy 2000, Washington D.C. http://www.esa.doc.gov/

US Department of Labor (1991) Dictionary of Occupational Titles (revised $4^{\text {th }}$ edition), Washington D.C: Government Printing Office.

Walker, P. and Liu, J. (1998) Baseline Indicators for Measuring Progress - Towards the Goals of RS\&T: 2010, Wellington: MoRST.

http://www.morst.govt.nz/pubs/base/index.htm

Willis, R. (1995) Ten years of change in New Zealand manufacturing employment. Morrison. P (ed.), Labour, Employment and Work in New Zealand 1994, Proceedings of the Sixth Conference, Institute of Geography, Victoria University of Wellington, 344-355.

\section{Appendix: The Classification of Information}

\section{Occupations over Time}

There have been major changes between the 1968 and the 1988 ISCO. The latter groups occupations by skill-level. It is therefore better suited for addressing questions concerning trends in higher-skilled versus lower-skilled information occupations, whereas the 1968 classification is task based, i.e. it groups together occupations that perform similar types of work. In NZ the 1988 ISCO was first used in the 1991 Census. There are difficulties in comparing some major occupation groups pre/post 1991. For ex- ample, more managerial classifications were introduced in 1991, and a certain number of clerical jobs are likely to have been re-classified as managerial, though the extent of this is difficult to determine (Statistics New Zealand, personal communication).

An earlier change in the classification of occupation data occurred between 1981 and 1986. For 1976 and 1981, the NZ work force comprises all persons 15 years of age and over who were normally employed for $\mathbf{2 0}$ hours or more each week (Department of Statistics, 1980, 1983). From 1986 onwards, only people who worked 30 hours or more were counted as full-time (Department of Statistics, 1988). The full-time occupation data were not corrected for this, as part-time employment prior to 1986 was relatively small. If this has introduced a bias, it should result in a slight overstatement of the full-time information work force for the earlier years.

The information occupations have been selected from fourdigit occupation data for each census. The total number of occupation groups identified in the Census has been greatly reduced over time, i.e. from 1155 in 1968 to 560 in 1996. For a detailed comparison of the NZ classifications, see Statistics New Zealand (1995, pp. 9-14). In order to increase comparability of the information work force estimates across the census years, the list of information occupations identified by Conway (1981) was modified as follows:

The 1976, 1981 and 1986 data identify 'supervisors, foremen' as separate categories. However, they can no longer be identified for 1991 and 1996. Instead, they are classified as belonging to the (usually non-information) occupations that they supervise (see Statistics New Zealand, 1995, p. 13). It was decided to exclude 'supervisors, foremen eic.' from the earlier years.

Some other information occupations identified for 1976 could not be identified separately for 1991 and 1996 at any level of detail and have been excluded from the 1976, 1981 and 1986 data. They had so few people employed that their exclusion did not greatly affect the estimates. They are: Hospital matrons (189 people in 1976), newsvendors and agents (306 people in 1976), fabric examiners (149 people in 1976), private investigators (36 people in 1976).

\section{Commercial travellers have been included.}

All information occupations classified by Conway as belonging to the Services category have been neglected: Housekeepers, chief stewards, head cooks, chefs, private and store detectives.

All information occupations classified by Conway as belonging to Agriculture, i.e. forest and logging managers and supervisors, have been put into group A for 1976, 1981 and 1986 (they are included in that group for 1991 and 1996). 
Messengers: Not included for 1991 and 1996, but included for earlier years.

It should also be noted that Conway (1981) included the unemployed in his count of information workers. In this study the unemployed are excluded for all years, i.e. the focus is on people gainfully employed.

To sum up, the combined effect of the changes to Conway's

\section{Table A1: Information Occupations at the 4-Digit Level, 1996 Census.}

A. Professional, technical

2111 Physicists and Astronomers

2112 Meteorologists

2113 Chemists

2114 Geologists and Geophysicists

2121 Mathematicians, Statisticians and

Related Professionals

2131 Computing Professionals

2141 Architects, Town and Traffic Planners

2142 Civil Engineers

2143 Electrical Engineers

2144 Electronic and Telecommunications

Engineers

2145 Mechanical Engineers

2146 Chemical Engineers

2147 Mining Engineers, Metallurgists and

Related Professionals

2148 Cartographers and Surveyors

2211 Biologists, Botanists, Zoologists and

Related Professionals

2212 Microbiologists and Related

Professionals

2213 Agricultural Scientists

2221 Medical Doctors

2225 Dietitians and Public Health

Nutritionists

2226 Other Health Professionals (Except

Nursing)

2311 Tertiary Teaching Professionals

2321 Secondary Teaching Professionals

2331 Primary Teaching Professionals

2332 Early Childhood Teaching

Professionals

2341 Special Education Teaching

Professionals

2351 Education Advisors

2352 Education Reviewers

2411 Accountants

2412 Personnel Professionals

2413 Other Business Professionals

2421 Barristers and Solicitors

2422 Judges

2423 Other Legal Professionals

2431 Archivists and Curators

2432 Librarians and Related Information

Professionals

2441 Economists

2442 Social Scientists

2443 Philologists, Translators and estimate turned out to be relatively minor. The proportion of the information work force in the total classified work force in 1976 falls from $35.9 \%$ to $34.6 \%$. The major differences are the exclusion of supervisors, and the inclusion of all sales representatives. To give an indication of the information occupations identified, the complete 1996 list of 112 occupations is shown below in Table A1. Further details are provided in the additional appendices in Engelbrecht (2000a).

\begin{tabular}{ll}
2441 & Psychologists \\
2442 & Counsellors \\
3112 & Civil Engineering Technicians \\
3113 & Electrical Engineering Technicians \\
3114 & Electronic Engineering Technicians \\
3118 & Draughting Technicians \\
3119 & Other Engineering Technicians \\
3141 & Ships' Engineers \\
3221 & Opticians \\
3324 & Statistical and Mathematical \\
& Associate Professionals \\
3341 & Social Work Associate Professionals \\
3342 & Education Associate Professionals \\
3351 & Careers and Employment Advisors \\
3361 & Authors, Journalists and Other \\
& Writers \\
3362 & Sculptors, Painters and Related \\
& Artists \\
3363 & Decorators and Commercial \\
& Designers \\
3364 & Composers, Musicians and Singers \\
3365 & Choreographers and Dancers \\
3366 & Film, Stage and Related Actors and \\
3367 & Directors \\
& Radio, Television and Other \\
3368 & Announcers \\
\hline & Clowns, Magicians, Acrobats and \\
& Related Workers \\
\hline
\end{tabular}

B. Administrative and managerial

1111 Legislators

1121 Senior Government Administrators

1131 Senior Business Administrators

1141 Special-Interest Organisation

Administrators

1211 Corporate Managers or Managing

Directors

1221 Production and Operation Managers

1222 Finance and Administration

Managers

Human Resources Managers

1224 Sales and Marketing Managers

1225 Advertising and Public Relations

Managers

1227 Computing Services Managers

1228 Research and Development

Managers

Other Specialised Managers

Other Government Professionals 


\section{Clerical}

3121 Computer Equipment Controllers

3144 Air Traffic Controllers

3321 Administrative and Related

Associate

Professionals

3322 Legal and Related Business

Associate Professionals

3323 Bookkeepers

3331 Customs and Border Inspectors

4111 Typists and Word Processor

$$
\text { Operators }
$$

4112 Data Entry Operators

4114 Secretaries

4121 Accounting and Bookkeeping Clerks

4122 Statistical and Finance Clerks

4131 Stock Clerks

4132 Production Clerks

4133 Transport Clerks

4141 Library and Filing Clerks

4142 Mail Carriers and Sorting Clerks

4143 Coding, Proof Reading and Related

Clerks

4144 Office Clerks

4215 Bill, Debt and Related Cash

Collectors

4221 Receptionists and Information Clerks

4222 Telephone Switchboard Operators

\section{Sales workers}

1226 Supply and Distribution Managers

3311 Securities and Finance Dealers and

Brokers

3312 Insurance Representative

3313 Real Estate Agents

3314 Travel Consultants and Organisers

3315 Technical and Commercial Sales

Representatives

3316 Buyers

3317 Appraisers and Valuers

3318 Auctioneers

3319 Other Finance and Sales Associate

Professionals

\section{E. Production workers}

3131 Photographers and Image and Sound

Recording Equipment Controllers

3132 Broadcasting and

Telecommunications Equipment

Controllers

3151 Safety and Health Inspectors

7242 Electronics Fitters and Servicers

7243 Radio and Television Servicers

7331 Printing Trades Workers
Private Bag 11222

Palmerston North

H.Engelbrecht@massey.ac.nz

http://econ.massey.ac.nz/hje/ 